УДК 94 (477) : 37.035 «1956/1991»

DOI: https://doi.org/10.33782/eminak2019.4(28).354

\title{
ГРОМАДЯНСЬКЕ ВИХОВАННЯ: РАДЯНСЬКА ПРАКТИКА (1956-1991 РP.)
}

\author{
Олена Шановська \\ Одеський національний політехнічний університет (Одеса, Україна) \\ e-mail: baku1589@gmail.com \\ ORCID: https://orcid.org/0000-0001-9634-2598
}

Представлено загальну модель організації громадянського (комуністичного) виховання у радянській Україні другої половини ХХ ст. Аналізується процес формування у радянських громадян системи соціально-політичних цінностей, установок, що забезпечували легітимність партійно-радянської системи. Увагу акцентовано на процесі політичної соціалізації, що відбувалася впродовж всього життя. Доведено, що політична соціалізація була скерована партією та державними органами, мала комуністичноорієнтовану світоглядну спрямованість і практично була зведена до ідеологічного виховання.

Ключові слова: комуністичне виховання, політична соціалізація, громадянський обов'язок, комуністична ідеологія, радянська пропаганда

У сучасній інтелектуальній літературі вказується, - і цьому знаходимо підтвердження, що радянське минуле продовжує нуртувати у суспільній свідомості. Наші уявлення про радянську епоху, отримані з вивчення різних досвідів, свідчень, дозволяють збагнути логіку її тривання та позбутися присутності минулого у сучасному, надають можливість наповнити нашу реальність іншим світоглядним змістом.

Проблема громадянського виховання актуалізується у зв'язку зі схваленням 3 жовтня 2018 р. Кабінетом Міністрів України Концепції розвитку громадянської освіти в Україні. В цьому плані вивчення успішного радянського досвіду викликає чималий інтерес. Звичайно, мова не йде про виховання, як за часів СРСР, одержавлених громадян. Виховний процес повинен орієнтуватися на духовні цінності українського народу, загальнолюдські цінності та соціально-політичні цінності громадянського суспільства. Йдеться про необхідність формування громадянськості як готовності та здатності українців до активної участі у справах суспільства та держави на основі глибокого усвідомлення своїх прав і обов'язків, що передбачає розвиток політичної та правової свідомості, почуття патріотизму, усвідомлення причетності до історичної долі своєї вітчизни та її народу1.

Факт лишається фактом: у СРСР існувала ретельно продумана програма комуністичного виховання, що забезпечувала визнання радянськими людьми спільності власних і державних інтересів, ототожнення себе з існуючим соціалістичним суспільним ладом, почуття громадянського обов'язку, гордості за свою країну. Звідси громадянська звага у захисті вітчизни, піднесення патріотичних настроїв тощо. Попри партійно-державний контроль за всіма сферами суспільного та культурного

\footnotetext{
1 Горбатенко В.П. Громадянськість // Політологічний енциклопедичний словник / Упорядник В.П. Горбатенко; За ред. Ю.С. Шемшученка, В.Д. Бабкіна, В.П. Горбатенка. 2-е вид., доп. і перероб. Київ: Генеза, 2004. С. 122.
} 
життя, політизацію й ідеологізацію, певні методи та форми правового, патріотичного виховання можна використовувати й у сучасних реаліях.

Проблема комуністичного виховання була пов'язана з провідним трендом в історіописанні радянської доби - темою комуністичного будівництва та належала до пріоритетної тематики республіканської соціогуманітаристики, навіть була затверджена як «загальноакадемічна». Маса публікацій на цю тему, крім усього іншого, друкувалася видавництвом політичної літератури України («Політвидав України») i мала пропагандистське призначення. У пострадянський період зазначена проблема певною мірою знайшла відображення у публікаціях фахівців-педагогів, а також наукових розвідках Ю.О. Каганова², Я.М. Пилинського 3.

Відтворення глибинної реальності, внутрішньої дійсності радянського світу, що становить підгрунтя сьогодення, залишається на часі. Це ставить завдання сконструювати новітню візію радянської епохи, що, врешті-решт, дасть змогу позбутися політичних цінностей минулого, міфів і стереотипів, що засіли у країні, в колективній та індивідуальній пам'яті, у переконаннях та ідеях. У запропонованій статті представлено загальну модель організації громадянського виховання у СРСР. Аналізується процес формування у радянських громадян системи соціально-політичних цінностей, установок, які зумовлювали мотиви їхньої поведінки та забезпечували стабільність радянської політичної системи.

У «Країні рад» з ідеологічних міркувань першочергового значення надавалося виховному процесу. Як писав великий український виховник Григорій Ващенко, основне завдання радянської школи та педагогіки полягало у тому, «щоб підготувати борців за комунізм, інакше кажучи, виховати із молоді покірне знаряддя в руках комуністичної партії»4. Увага до проблем політичного виховання радянських громадян знайшла відображення у виступах вищих партійних діячів, конституціях, партійних документах, наукових виданнях. Згідно з риторикою партійних апологетів, завдання комуністичного виховання включало формування у радянських людей марксистсько-ленінського світогляду, непримиренності до інших ідеологій і боротьбу з ними, відданості комуністичній партії та, відповідно, її вождям, виховання «у всіх трудящих почуття радянського патріотизму, гордості за соціалістичну Батьківщину, за великі звершення народу, інтернаціоналізму, непримиренності до виявів націоналізму, шовінізму та національної обмеженості...»5. У програмах і постановах пленумів ЦК КПРС постійно наголошувалося на необхідності підвищення політичної пильності та протидії так званим «класовим ворогам», на тому, щоб «вести розгорнутий наступ проти імперіалістичної ідеології, проти пережитків минулого у свідомості людей»6.

Стандарти політичного життя радянського суспільства визначали особливості політичної соціалізації, що була скерована партією та державними органами, мала комуністично-орієнтовану світоглядну спрямованість i, практично, була зведена до

\footnotetext{
2 Каганов Ю.О. Радянські свята та обряди у контексті ідеологічної політики в Україні другої половини XX ст. // Наукові праці історичного факультету Запорізького національного університету. 2013. № 36. С. 186-194.

3 Пилинський Я.М. Громадянська освіта в Україні // Наукові записки НаУКМА. 2016. Т. 186: Політичні науки. С. 61-66.

4 Ващенко Г. Виховний ідеал («Записки Виховника»). Брюссель-Торонто-Нью Йорк-ЛондонМюнхен: Вид-во Центральної управи Спілки української молоді, 1976. С. 17.

${ }^{5}$ Калинин М.И. О воспитании коммунистической сознательности. Москва: Политиздат, 1974. С. 6. 6 КПСС. ЦК. Пленум. 1963. Июнь. Стенографический отчет. Москва: Политиздат, 1963. С. 7.
} 
ідеологічного виховання.

Формування комуністичної свідомості розпочиналося у дитячому садку, продовжувалося у перших класах «жовтенят», піонерських загонах, комсомольських таборах. Школярам вселяли упевненість у неминучому торжестві ленінських ідей у світі та віру в щасливе життя у радянській країні, сповнене колективною, дружною, вільною працею. Адже, як тлумачилося, Жовтнева революція відкрила нову еру в історії людства, повсталий народ скинув експлуататорів і встановив владу робітників і селян, створивши умови для побудови справедливого та гуманного комуністичного суспільства. Дітей повчали бути гідними великої країни, їм прищеплювали почуття історичної відповідальності, розуміння нероздільності особистих інтересів із державною необхідністю7.

Священна вітчизна була нерозривно пов'язана з ім'ям радянського вождя: школярі повинні були «вчитися, вчитися і вчитися, як заповідав великий Ленін», «жовтенята», названі на честь «Великої Жовтневої соціалістичної революції» носили значок із зображенням Леніна, Всесоюзна піонерська організація носила ім'я В.I. Леніна, комсомольці були об’єднані у Всесоюзний ленінський комуністичний союз молоді (ВЛКСМ).

У радянській школі моральне виховання було невід'ємною складовою навчального процесу. Воно поєднувалося з атеїстичним та інтернаціональним вихованням. Від педагогічних колективів вимагалося здійснювати свій важливий внесок у «виконання величних накреслень Програми КПРС», втілювати у життя висловлені на партійних з'їздах настанови на необхідність підвищення моральної відповідальності радянських людей, зокрема, підростаючого покоління, на виконання ними громадянського обов'язку, на «поліпшення ідеологічної роботи з молоддю, щоб кожний юнак і кожна дівчина стали переконаними бійцями за комуністичні ідеали»8.

Прищеплювання учням почуття громадянського обов'язку будівника комунізму здійснювалося, перш за все, у процесі викладання історії та суспільствознавства. Із середини 1960-х рр. в усіх середніх школах було введено спеціальний курс суспільствознавства, з 1972 р. була запроваджена обов'язкова початкова військова підготовка, а з 1975 р. учні восьмих класів почали вивчати предмет «Основи радянської держави і права»9.

Передові історики, обмінюючись досвідом із колегами, підкреслювали, що вчитель повинен роз'яснювати смисл громадянського обов'язку, домагатися, щоб учень сприймав суспільні інтереси як свої власні, щоб ознайомлюючись з тим або іншим проявом громадянського обов'язку, учень діставав чітку уяву про те, наскільки його дії відповідають інтересам суспільства. Від учителів вимагалося вміло підбирати факти й ілюстративний матеріал, який би демонстрував перспективи комуністичного будівництва, керівну та спрямовуючу роль комуністичної партії, прославляв ідейних комуністів-ленінців. Як наголошувалося, могутнім джерелом виховання ідейної переконаності та комуністичної моральності учнів було ознайомлення їх з життям і

\footnotetext{
7 Козырев Г. Об идеологическом воспитании в CCCP (в воспоминаниях и оценке очевидца). URL: http://kozyrev-gi.ru/pages/ob-ideologicheskom-vospitanii-v-sssr/

8 Пєтухов Є.І. Виховання в учнів почуття громадянського обов'язку будівника комунізму на уроках історії СРСР // Український історичний журнал. 1967. № 3. С. 109.

${ }_{9}$ Калініченко В.В., Рибалка І.К. Історія України. Ч. ІІІ: 1917-2003 рр.: Підручник для історичних факультетів вищих навчальних закладів. Харків: ХHУ ім. В.Н. Каразіна, 2004. URL: http://wwwhistory.univer.kharkov.ua/old/e-library/kalinichenko_textbook/Kalinichenko_9.3.htm
} 
діяльністю В.І. Леніна, героїчною історією партії, радянського народу та комсомолу.

Масово обладнувалися ленінські кімнати, ленінські зали, а в багатьох школах музеї Леніна. У 1966 р. тільки у Львівській області діяло 56 музеїв, 193 кімнати і 280 куточків Леніна. Загалом по республіці їх було більше 10 тисяч 10.

Значної уваги приділялося вихованню почуттів радянського патріотизму на героїчних традиціях, прищепленню учням нетерпимого ставлення до будь-яких проявів аполітичності, нігілізму і т.д. Як приклади невичерпної мужності, героїзму, самовідданої готовності до самопожертви на уроках наводилися факти боротьби робітників проти царського самодержавства, жовтневих подій 1917 р., подвиги радянської молоді у роки громадянської та Великої Вітчизняної війни.

Про героїчні подвиги піонерів, комсомольців, партизанських командирів школярі дізнавалися не тільки на уроках, а й під час позакласної та позашкільної роботи. Крім відвідання музеїв, історичних місць, пов'язаних із бойовими діями та партизанським рухом, участі у краєзнавчих експедиціях, учні проводили збори дружин і загонів, конференції. У палацах піонерів, школах організовувалися музеї піонерської, партизанської та бойової слави.

У школах проводилася позакласна атеїстична робота: були створені гуртки, товариства, клуби юних атеїстів, шкільні атеїстичні музеї, якими керували досвідчені вчителі11.

Вихованню молоді в дусі радянського патріотизму та колективізму значним чином сприяли свята, які влаштовували школи разом із ветеранами праці та війни. Свято викликало сильне емоційне піднесення та переживання, а тому було досить зручним для пропаганди соціалістичних ідей, прилучення радянських людей, зокрема молоді, до політичних цінностей. Інституціалізація свят та їх постійність дозволяли закріпити емоційні переживання населення на рівні підсвідомості12. Пропаганда включала також проведення демонстрацій на підтримку влади. Під час державних свят у річниці Жовтневої революції 7-8 листопада та День міжнародної солідарності трудящих 1-2 травня організовувалися масові урочисті всенародні ходи 3 портретами вождів, членів Політбюро ЦК КПРС, червоними прапорами, транспарантами з комуністичними лозунгами, емблемами із зображеннями червоної зірки, серпа і молота й іншою політичною символікою. Масові святкові ходи під патріотичні гасла й урочисті пісні, лозунги та комуністичні символи значним чином сприяли формуванню радянської ідентичності та комуністичної свідомості громадян.

У процесі професійного навчання також першочергової уваги приділялося ідейно-виховній роботі, зокрема, вихованню юнаків і дівчат у дусі високих комуністичних ідеалів сприяли вивчення студентською молоддю марксизму-ленінізму в рамках навчальних програм, роботи факультетських студентських лекторіїв, де читалися лекції, присвячені діяльності Леніна, ленінській теоретичній спадщині, а також боротьбі КПРС за побудову комуністичного суспільства. 31956 р. на виконання постанови ЦК КПРС замість курсу основ марксизму-ленінізму у радянських вишах були введені три загальнообов'язкові дисципліни: історія КПРС, політекономія, діалекти-

10 Кобзар Б.С. Виховувати учнів на героїчних традиціях // Український історичний журнал. 1966. № 5. C. 112.

11 Курносов Ю.О. Роль інтелігенції України в комуністичному вихованні трудящих. Київ: Наукова думка, 1968. С. 155.

12 Шаповалов С.Н. Советские праздники и политическая социализация молодежи // Общество: Политика, Экономика, Право. 2013. № 3. С. 30. 
чний та історичний матеріалізм. Згодом були запроваджені факультативні курси марксистсько-ленінської етики, марксистсько-ленінської естетики, наукового атеїзму. У 1963 р. до навчальних планів вишів був уведений загальнообов'язковий курс наукового комунізму із складанням держіспиту13.

Про те, що виховну роботу було поставлено на наукову основу, свідчили такі факти: викладачі кафедри марксизму-ленінізму Одеської консерваторії перед початком викладання курсу з основ марксистської етики, проводили серед студентів анкетне опитування з деяких проблем моралі та з урахуванням цього читали свої лекції. Вивчення практичної діяльності, ділових і морально-політичних якостей молодих фахівців - випускників львівських вузів проводив у жовтні 1964 р. Львівський обком комсомолу спільно з комсомольськими організаціями навчальних закладів. При цьому враховувалася думка про молодих фахівців робітників, керівників підприємств, колгоспів і радгоспів, партійних і комсомольських організацій ${ }^{14}$.

У позанавчальний час викладачі здійснювали агітаційну ідейно-виховну роботу спільно з комсомольськими, профспілковими організаціями, студентськими науковими товариствами, організаціями ДТСААФ (Всесоюзне Ордену Червоного Прапора Добровільне товариство сприяння армії авіації і флоту), організовуючи проведення політінформацій, тематичних вечорів, диспутів на актуальні злободенні теми, зустрічей студентської молоді з ветеранами, ударниками комуністичної праці15.

В партії, в її середніх і вищих ланках цикл політичної соціалізації завершувався. «Моральний кодекс будівника комунізму», що містив новий «Статут КПРС», прийнятий XXII з'їздом КПРС (17-31 жовтня 1961 р.), передбачав класову оцінку, політичний підхід і формування цінностей комуністичної ідеології - народовладдя, рівності, суспільної власності, інтернаціоналізму. Культивувався комунітаризм - пріоритет групової справедливості перед принципами індивідуальної свободи особистості, - кодекс декларував свободу і братерство трудящих, сумлінну працю на благо суспільства: хто не працює, той не їсть, турботу кожного про збереження та помноження суспільного надбання, високу свідомість громадського обов'язку, нетерпимість до порушень суспільних інтересів, колективізм і товариську взаємодопомогу: один за всіх і всі за одного, інтернаціональну солідарність. Кодекс орієнтував на захист класових політичних інтересів - серед найвищих вимог комуністичної моралі були відданість справі комунізму, любов до соціалістичної Вітчизни, непримиренність до класових ворогів і т.ін.

Вступ у партійні ряди КПРС створював умови для професійної кар'єри, надавав можливість займатися улюбленою справою з найменшими обмеженнями, з більш широким доступом до інформації, до «закритих» винаходів, видань, документів, виїжджати за кордон та ін. Трудові успіхи були неможливі без активної громадської роботи, насамперед у масових організаціях - комсомолі та профспілках, у добровільних товариствах, секціях, гуртках і т.ін.

Політико-виховна робота у навчальних закладах, трудових колективах продовжувалася у громадській діяльності, участі у різних заходах - відзначеннях державних

\footnotetext{
13 Ткачук М. Філософська освіта в радянській Україні: досвід осмислення історичних документів та архівних матеріалів // Філософська думка. 2010. № 6. С. 62.

14 Питов В., Попов В. Учиться коммунизму (из опыта воспитательной работы в вузах Украинской ССР). Киев: Изд-во полит. лит. Украины, 1965. С. 251-252.

15 Меженін М.М., Замелан В.А. Ідейно-виховна робота з студентами у позанавчальний час // Український історичний журнал. 1969. № 12. С. 112-114.
} 
свят, суботниках, проведенні політінформацій, лекцій, дискусій з нагальних питань соціально-моральної практики, де значна увага приділялася «науковому» викриванню буржуазної ідеології, буржуазних порядків, звичаїв і способу життя та роз'ясненню безумовних переваг радянських цілей і цінностей. Таким чином здійснювалася реалізація офіційно проголошеної настанови на забезпечення нерозривного зв'язку інтересів особистості та суспільства.

Суттєвий внесок у формування комуністичних світоглядних і ціннісних настанов у радянських трудящих вносила система партійної освіти. При ЦК КПРС існувала Академія суспільних наук - вищий партійний навчальний заклад 3 підготовки працівників центральних партійних установ, ЦК компартій союзних республік, обкомів і райкомів, викладачів вишів, працівників партійно-політичних видань. У 1964 р. при академії був створений Інститут наукового атеїзму. Центральними партійними установами з дослідження історії КПРС, міжнародного комуністичного руху, пропаганди творів К. Маркса, Ф.Енгельса, В.Леніна, партійних документів і, водночас, центрами вищої політичної освіти у системі партійного навчання були університети марксизму-ленінізму при ЦК КПРС, ЦК партії союзних республік, міськкомах партії.

В університетах навчалися без відриву від виробництва партійні, радянські, працівники народного господарства, працівники культури, переважно з вищою освітою, направлені первинними партійними організаціями з метою підвищення їхнього ідейно-теоретичного рівня16. Диплом про закінчення університету марксизмуленінізму був чи не обов'язковою умовою висунення на будь-яку керівну посаду.

Крім освітніх закладів, політичне навчання радянських трудящих проводилося у гуртках, на семінарах. Гуртками керували і молоді спеціалісти, і ветерани праці. Первинними партійними організаціями підприємств, установ, радгоспів, колгоспів створювалися колективи агітаторів для проведення комуністичної агітації 17.

Значну роль у системі партійної освіти відігравала інтелігенція, організована у численне та представницьке Всесоюзне товариство «Знання». Членами товариства були вчені, інженери, викладачі, лікарі, вчителі, працівники партійного та державного апарату, письменники, журналісти, новатори виробництва. Перед ними стояло відповідальне завдання - доносити комуністичне вчення до всіх верств населення, в усі куточки республіки. Впродовж 1959-1965 рр. кількість членів товариства «Знання» в Україні зросла більше, як у два рази - з 200 тисяч до 423 тисяч чоловік. За деякими даними, загалом в Україні кількість слухачів різних форм політичного навчання з 1959/60 по 1964/65 учбовий рік зросла з 2,3 млн. чоловік до 5,5 млн. ${ }^{18}$.

У 1984-85 навчальному році у системі партійного навчання було задіяне більше 2,3 млн. комуністів і безпартійних. Ще більше 1,3 млн. чоловік оволодівали основами політики партії у масових формах політичного навчання і майже 6,6 млн. - у системі економічної освіти ${ }^{19}$.

Форми та методи масово-політичної роботи серед трудящих були різноманітними. Комуністичне виховання мас забезпечували і відкриті партійні та робочі збори у

\footnotetext{
16 Университеты марксизма-ленинизма // Большая советская энциклопедия. В 30-ти томах. Москва: Советская энциклопедия. 1969-1978. URL: https://biblioclub.ru/index.php?page $=$ dict\&termin $=751076$

17 Гаєвський А.М. Збагачення форм і методів масово-політичної роботи КП України серед трудящих (1963-1965рр.) // Український історичний журнал. 1966. № 3. С. 27.

18 Курносов Ю.О. Роль інтелігенції України в комуністичному вихованні трудящих. С. 41, 53.

19 Крючков Г.К. Про шляхи підвищення ефективності партійної роботи // Український історичний журнал. 1984. № 12. С. 8.
} 
трудових колективах - так звані «збори трудящих», які розглядалися як колективні органи управління. На зборах обговорювалося питання дотримання працівниками принципів «Морального кодексу будівельника комунізму». Зборам, як правило, передувала ретельна підготовка за участю громадськості. Вивчалася моральнопсихологічна обстановка в цілому на підприємствах, в організаціях, у наукових колективах, підрозділах, службові взаємовідносини між працівниками, їхня участь у громадській діяльності, аналізувалися конкретні результати політико-виховної діяльності партійних, профспілкових, комсомольських, інших громадських організацій. Така робота завершувалася визначенням заходів із подальшого вдосконалення ідейно-морального виховання, часто - виробленням і прийняттям «Кодексів трудової честі».

Сприяли розгортанню політичної агітації відзначення свят - Дні механізаторів, Дні буряководів, Дні тваринників, що були близькими за своєю формою до зборів, так само, як і семінари, науково-теоретичні конференції, вечори запитань і відповідей, повсякденні індивідуальні та групові бесіди агітаторів у постійно діючих агітпунктах, особливо у сільській місцевості. Там, де не було відповідних приміщень, вони розміщувалися у хатах жителів - так званих «Агітхатах», «Домашніх агітпунктах» і навіть в агітмашинах райкомів партії, які виїжджали на поля у літній період, у сільських агітбесідках, а також на агітмайданчиках у містах, що також діяли у літній період. Таких агітмайданчиків, де за участю секретарів парторганізацій, господарських і профспілкових керівників проводилися бесіди, вечори запитань і відповідей, диспути, перегляд кінофільмів, у республіці в 1965 р. було понад 10 тисяч20.

Широка пропаганда норм і принципів комуністичної моралі здійснювалася засобами масової інформації: у всіх газетах і журналах були відповідні рубрики та розділи; наступальний дух у масово-політичній роботі мали «Бойові листки», «Блискавки», бюлетені змагання «Хто сьогодні попереду», сатиричні «Крокодили», «Перці», «Їжаки», «Терниці» й ін.; роками діяв телевізійний університет радянського університету «Акценти».

Агітатори, вчителі у школах, викладачі у вишах масово пропагували твори К. Маркса, Ф. Енгельса, В. Леніна, рішення з'їздів і пленумів Комуністичної партії, які виходили у світ мільйонними тиражами. Як зазначав у 1983 р. секретар ЦК КПРС К. Черненко, загальний тираж творів класиків марксизму-ленінізму за роки радянської влади становив понад 700 млн. примірників 21.

Відтак, радянська система освіти виявилася дійсно «третім фронтом» (поряд із обороною та промисловістю), який створював «підготовлених людей» 3 відповідною «новою культурою в сфері почуття» 22.

Таким чином, у зорганізованій радянській державі легітимність партійнорадянської системи забезпечували цінності й установки політичної культури, ідеологія, політична соціалізація. Політична соціалізація відбувалася впродовж усього свідомого життя громадян і практично була зведена до комуністичного виховання, що тривко проникало в усі сфери суспільно-культурного життя. Виховання нової

\footnotetext{
20 Гаєвський А.М. Збагачення форм і методів масово-політичної роботи КП України серед трудящих... С. 19. Посилання на поточний архів відділу пропаганди і агітації ЦК КП України за 1965 р. 21 Пленум Центрального Комітету КПРС, 14-15 червня 1983 р.: Стенографічний звіт. Київ: Політвидав України, 1983. С. 20.

22 Цветаева Н.Н. Биографические нарративы советской эпохи // Социологический журнал. 2000. № 1-2. C. 170.
} 
людини, отже, й повне подолання пережитків минулого у свідомості людей розглядалися як невід'ємні складові комуністичного будівництва. Політична соціалізація мала досить жорсткий характер, орієнтований винятково на комуністичну систему цінностей і здійснювалася контрольованими інститутами соціалізації. До таких інститутів належали: сім'я, середні та вищі навчальні заклади, громадські організації, державні структури, система партійно-політичної освіти, а також ЗМІ. Останні виступали не тільки самим оперативним джерелом актуальної інформації, але й були важливим засобом залучення людей до політичного життя, стимулювання їхньої політичної активності. Партійні комітети виступали у ролі «вихователя» суспільства у властивому дусі, забезпечували «колективну підтримку» рішень масами. Партійний контроль над всіма царинами суспільно-культурного життя забезпечувала система цензури, структура якої складалася з різних рівнів та охоплювала редакторську цензуру, контроль Головного управління зі справ літератури і видавництв (Головліт), цензуру держбезпеки, ідеологічну цензуру.

Незважаючи на загалом облудну настанову, членство у масових дитячих та юнацьких організаціях у сукупності з іншими видами освіти та виховання сприяло розвитку почуттів колективізму, народної солідарності та гордості за велику та могутню радянську державу. Показово, що чим більшу кількість ступенів освіти (факультет заочного навчання, технікум, курси, інститут тощо) проходила людина, тим сильніше вона була схильна захищати свою прихильність радянським ідеалам, незважаючи на протиріччя між логікою викладеної нею історії життя та логікою цих ідеалів.

У сучасній Україні, незважаючи на різницю поколінь, які представлені у суспільно-політичному середовищі, більшість населення проходила первинну соціалізацію за радянських часів. Даний факт суттєво впливає на політичну свідомість громадян, адже політичне виховання, як і будь-яке інше, розпочинається у сім'ї, і суспільство все ще зберігає різноманітні політичні інтереси та потреби людей, які включаються у політичне життя.

\section{REFERENCES}

Haievskyi, A. (1966). Zbahachennia form i metodiv masovo-politychnoi roboty KP Ukrainy sered trudiashchykh (1963-1965 rr.) [Enrichment of the forms and methods of mass-political work of the Communist Party of Ukraine among the working people (1963-1965)]. Ukrainskyi istorychnyi zhurnal, 3, 15-28 [in Ukrainian].

Horbatenko, V. (2004). Hromadianskist [Citizenship]. In Politolohichnyi entsyklopedychnyi slovnyk, (p. 122). Kyiv: Heneza [in Ukrainian].

Kahanov, Y. (2013). Radianski sviata ta obriady u konteksti ideolohichnoi polityky v Ukraini druhoi polovyny XX st. [Soviet holidays and ceremonies in the context of ideological policy in Ukraine in the second half of XX century]. Naukovi pratsi istorychnoho fakultetu Zaporizkoho natsionalnoho universytetu, 36, 186-194 [in Ukrainian].

Kalinichenko, V. \& Rybalka, I. (2004). Istoriia Ukrainy. Chastyna III: 1917-2003 rr. [History of Ukraine. Part III: 1917-2003]. Kharkiv [in Ukrainian].

Kalinin, M. (1974). O vospitaniyi kommunisticheskoi soznatelnosti [On the upbringing of communist consciousness]. Moskva [in Russian].

Kobzar, B. (1966). Vykhovuvaty uchniv na heroichnykh tradytsiiakh [Educate students in heroic traditions]. Ukrainskyi istorychnyi zhurnal, 5, 111-114 [in Ukrainian].

Kozyrev, G. Ob ideologicheskom vospitanii $v$ SSSR $v$ vospominaniiakh i otsenke ochevidtsa [Ideological education in the USSR (in the memories and assessment of the eyewitness)]. Retrieved from http://kozyrev-gi.ru/pages/ob-ideologicheskom-vospitanii-v-sssr/ [in Russian].

Kriuchkov, H. (1984). Pro shliakhy pidvyshchennia efektyvnosti partiinoi roboty [About ways to increase the effectiveness of party work]. Ukrainskyi istorychnyi zhurnal, 12, 5-16 [in Ukrainian]. 
Kurnosov, Y. (1968). Rol intelihentsii Ukrainy v komunistychnomu vykhovanni trudiashchykh [The role of the Ukrainian intelligentsia in the communist upbringing of the working people]. Kyiv [in Ukrainian].

Mezhenin, M. \& Zamelan, V. (1969). Ideino-vykhovna robota z studentamy u pozanavchalnyi chas [Ideal and educational work with students in extra-curricular time]. Ukrainskyi istorychnyi zhurnal, 12, 112-114 [in Ukrainian].

Pietukhov, Y. (1967). Vykhovannia v uchniv pochuttia hromadianskoho oboviazku budivnyka komunizmu na urokakh istorii SRSR [Educating students' sense of civic duty as a communist builder in the lessons of USSR history]. Ukrainskyi istorychnyi zhurnal, 3, 109-112 [in Ukrainian].

Pylynskyi, Y. (2016). Hromadianska osvita v Ukraini [Civic education in Ukraine]. Naukovi zapysky Naukma. Politychni nauky, 186, 61-66 [in Ukrainian].

Pitov, V. \& Popov, V. (1965). Uchitsa kommunizmu (iz opyta vospitatelnoi raboty $v$ vuzakh Ukrainskoi SSR) [To study communism (from experience of educational work in universities of the Ukrainian SSR)]. Kiev [in Russian].

Shapovalov, S. (2013). Sovetskie prazdniki i politicheskaia sotsializatsiia molodezhi [Soviet holidays and political socialization of youth]. Obshchestvo: Politika. Ekonomika. Pravo, 3, 30-33 [in Russian].

Tkachuk, M. (2010). Filosofska osvita v radianskii Ukraini: dosvid osmyslennia istorychnykh dokumentiv ta arkhivnykh materialiv [Philosophical education in Soviet Ukraine: experience of comprehending historical documents and archival materials]. Filosofska dumka, 6, 35-67 [in Ukrainian].

Tsvetaeva, N. (2000). Biograficheskie narrativy sovetskoi epokhi [Biographical narratives of the Soviet era]. Sotsiologicheskii zhurnal, 1-2, 150-163 [in Russian].

Vashchenko, H. (1976). Vykhovnyi ideal («Zapysky Vykhovnyka») [Educational ideal («Notes Vykhovnyk»)]. Briussel-Toronto-Niu York-London-Miunkhen [in Ukrainian].

\section{Olena Shanovska}

(Odessa National Polytechnic University, Odessa, Ukraine)

ORCID: https://orcid.org/0000-0001-9634-2598

\section{Civic Education: Soviet Experience}

The paper is devoted to the civic (communist) education of Soviet citizens in Soviet Ukraine of the second half of the $20^{\text {th }}$ century. The process of formation of social and political values and aims system providing the legitimacy of the Party and Soviet regime is analyzed in the paper.

Civic education took place during the process of socialization of the individual through the system of social relations and education. Political socialization was directed by the Party and state bodies, had a communist-oriented outlook and was practically reduced to ideological education. Formation of communist consciousness began in kindergarten, continued in the first classes of «Little Octobrists», pioneer detachments, Komsomol camps.

The main task of the Soviet school was to impart the sense of civic duty of the communism builder to the students. Forming of ideological conviction and communism morality was an integral part of the educational process and was combined with atheistic and internationalist education. Much attention was paid to the training of the feelings of Soviet patriotism based on the heroic history of the Party, its leaders, the heroic deeds of pioneers, Komsomol members, and red commanders during the Civil and World War II.

In the Party, in its middle and upper ranks, the cycle of political socialization completed. The «moral code of the communism builder» included a class assessment, political approach, and formation of communist ideology values - democracy, equality, public ownership, internationalism. Communitarianism, high awareness of civic duty, and an inseparability of personal interests with a state need were cultivated.

Officially approved holidays with mass demonstrations, the media, literature and the arts, films and television were widely used for political propaganda, the formation of communist ideology and political identity. The party education system contributed significantly to the formation of communist worldviews and values of Soviet workers. 
Despite the generally deceitful aims, the membership in mass children and youth organizations, together with other types of education and training, contributed to the identification of workers with the existing socialism social order, the development of collectivism feelings, national solidarity, and pride in the greatness of Soviet State.

Keywords: communism education, political socialization, civic duty, communism ideology, Soviet propaganda 